\title{
Detection of disseminated tumor cells in lymph nodes from patients with early stage non-small cell lung cancer
}

Ane Kongsgaard Rud ${ }^{1 *}$, Kjetil Boye ${ }^{1,2}, \varnothing y s t e i n ~ F o d s t a d{ }^{1}$, Siri Juell ${ }^{1}$, Lars H. Jørgensen ${ }^{3}$, Steinar Solberg ${ }^{3}$, Åslaug Helland ${ }^{2,4}$, Odd Terje Brustugun ${ }^{2,4}$ and Gunhild Mari Mælandsmo ${ }^{1,5}$

\begin{abstract}
Background: The regional lymph node involvement is a major prognostic factor in patients with non-small cell lung cancer (NSCLC) undergoing surgical resection. Disease relapse is common, suggesting that early disseminated disease is already present in the regional lymph nodes at the time of surgery, and that the current nodal staging classification might be suboptimal. Early detection of disseminated tumor cells (DTCs) in lymph nodes could potentially enable identification of subcategories of patients with high risk of disease relapse.

Method: Lymph node samples were collected from 128 NSCLC patients at the time of surgery and the presence of DTCs determined by immunomagnetic selection (IMS) using the MOC31 antibody recognizing EpCAM. Results obtained with IMS were compared to the pathological staging obtained by histopathology. Associations between the presence of DTCs and clinicopathological variables and patient outcome were investigated.

Results: DTCs were detected in $40 \%$ of the lymph node samples by IMS. Their presence was significantly associated with pN status as assessed by histopathology, and samples from $83 \%$ of the patients with lymph node metastases (pN1-2) had detectable DTCs. In the group of patients who were negative for lymph node metastases by standard histopathology (pNo) DTCs were detected in $32 \%$. The presence of DTCs was not associated with any other clinicopathological variables. Patients with IMS-positive samples showed decreased relapse free survival compared to patients with IMS-negative samples, but the difference was not statistically significant. The $\mathrm{pN}$ status was significantly associated with both relapse free and overall survival, but the presence of DTCs had no prognostic impact in the subcategory of patients with pNO status.
\end{abstract}

Conclusion: Our findings do not support further development of lymph node DTC detection for clinical use in early stage NSCLC.

Keywords: NSCLC, Disseminated tumour cells, Lymph nodes, Immunomagnetic selection, Prognosis

\section{Background}

Curatively intended surgical resection is the standard therapy for operable patients with early-stage non-small cell lung cancer (NSCLC), and the prognosis of these patients is closely related to disease stage [1]. The regional lymph node involvement is a major prognostic factor, and for complete surgical resection of NSCLC a systematic nodal

\footnotetext{
* Correspondence: anekkongsgaard@yahoo.com

${ }^{1}$ Department of Tumor Biology, Institute for Cancer Research, Oslo University Hospital, The Norwegian Radium Hospital, PO Box 4953, Nydalen, Oslo NO-0424, Norway

Full list of author information is available at the end of the article
}

dissection is recommended [2]. This allows pathological staging of the disease according to standardized definitions, and thereby decision of further treatment strategies. The fact that approximately half of the patients undergoing surgery experience disease relapse, suggests that disseminated tumor cells (DTCs) may be present already at the time of surgery [3]. In routine clinical practice, pathological evaluation of resected lymph nodes is done by standard histopathology, a method by which DTCs cannot be identified. The high recurrence rate after surgical resection of NSCLC indicates that current staging classifications are not able to accurately predict patient outcome 
and that the nodal staging might be suboptimal. Detection of DTCs to regional lymph nodes at the time of surgery could possibly facilitate identification of subcategories of patients with high risk of disease relapse, and thereby stratification of patient groups for adjuvant therapy.

Occult metastatic spread to the lymph nodes or distant sites has been the focus of research over many years, and has been reported under different terminology. The Union for International Cancer Control (UICC) has defined micrometastasis as clusters of tumor cells measuring between 0.2 and $2 \mathrm{~mm}$ in diameter, and isolated tumor cells as single tumor cells or small clusters of cells smaller than $0.2 \mathrm{~mm}$ [4]. Tumor cells that have spread to lymph nodes or bone marrow are often referred to as DTCs, whereas circulating tumor cells (CTCs) are used for single cells in blood [5]. A number of previous studies have addressed the prognostic value of detecting micrometastasis and DTCs in lymph nodes of NSCLC patients [6-23], but due to considerable differences in terminology, methodology and results, no conclusion can be drawn based on the existing literature. The methods used for detection have traditionally been immunohistochemistry (IHC) with antibodies targeting epithelial-specific proteins like cytokeratins [6-18], and molecular methods using RT-PCR for detection of tumoror epithelial cell specific mRNA transcripts [3, 19-25]. Our group has previously published a study where we investigated the presence of DTCs in bone marrow aspirates from patients undergoing lung cancer surgery by the use of immunomagnetic selection (IMS) [26]. In the present study we have used IMS to investigate the presence of DTCs in lymph node tissue prospectively collected from patients with early stage NSCLC undergoing curatively intended surgery. In the IMS method small magnetic particles coated with the antibody MOC31 which recognizes the epithelial marker EpCAM, are used to isolate tumor cells from the lymph nodes, allowing fast screening of as much as $2 \times$ $10^{7}$ cells. The objective of our study was to determine the incidence of lymph node DTCs, and to compare results obtained with IMS to the pathological staging obtained by histopathology. Additionally, we wanted to investigate the associations between the presence of
DTCs and clinical and histopathological variables, as well as to patient outcome.

\section{Methods \\ Patients}

Between November 2011 and September 2013 we included 183 patients with assumed or verified NSCLC who underwent curatively intended surgical resection at Rikshospitalet, Oslo University Hospital. The project was accepted by the institutional review board and Regional Ethics Committee (S-06402b), the patients received oral and written information and signed a consent form before entering the project. At the time of surgery all patients underwent radical resection of the primary tumor and dissection of the hilar and mediastinal lymph nodes. The excised lymph nodes were first divided into two parts, leaving half the node for routine pathological review and one half for research projects. One node from one lymph node station per patient was made available for IMS analysis. Fiftyfive patients were excluded from the study for the following reasons: histology other than NSCLC (13), inadequate material for analysis (41) and withdrawn consent (1). The total study population thus included 128 patients with histologically verified primary NSCLC. The resected tumor tissue and lymph nodes were processed for routine histopathological assessment, and the histological subtypes were classified according to WHO criteria [27]. Tumors were staged according to the Union for International Cancer Control (UICC), TNM 7, and histopathological parameters were retrieved from the pathology reports. After surgery, the patients were followed by clinical evaluation and radiological examination in their corresponding local hospitals according to national guidelines. We collected the follow-up information from the patients' local hospitals. Survival data were obtained from the National Registry of Norway and updated on January 30th, 2015.

\section{Immunomagnetic selection}

The immunomagnetic selection was performed as described previously $[28,29]$, and a schematic drawing of the method is shown in Fig. 1. The lymph node tissue

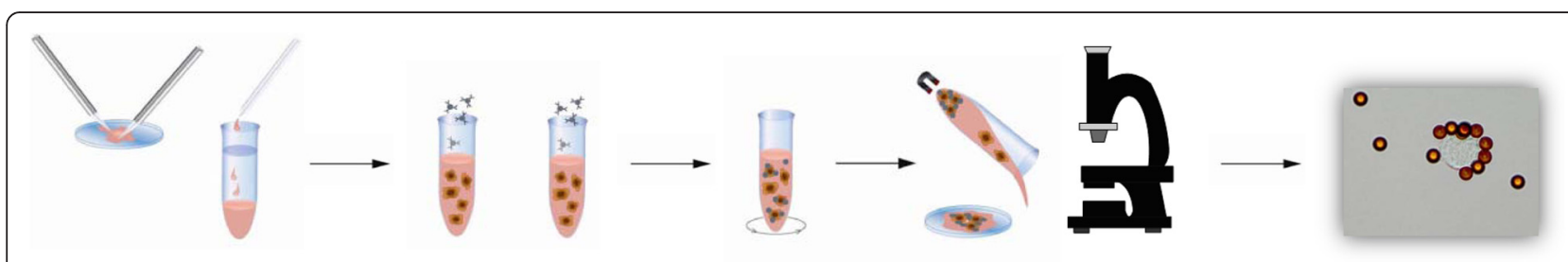

Fig. 1 Schematic overview of the IMS technique. Fresh lymph node samples were disintegrated in sterile PBS, followed by filtration, centrifugation, dilution and aliquotation of the cell suspensions. The cells were then mixed with either MOC31 coated magnetic beads (anti-EpCAM) or beads without antibodies for control. The samples were incubated under continuous rotation at $4^{\circ} \mathrm{C}$ for $30 \mathrm{~min}$, and placed on a magnet to separate bead-bound and unbound cells. The supernatant containing the unbound cells was removed, and fractions of the cell suspension were examined in the light microscope 
was placed in a petri dish containing $10 \mathrm{ml}$ phosphate buffered saline (PBS) containing $1 \%$ human serum albumin (HSA) for disaggregation using scalpels. The disaggregated tissue was then filtered through a $70 \mu \mathrm{m}$ cell strainer (BD Biosciences, Franklin Lakes, NJ, USA) into a $50 \mathrm{ml}$ tube, and the cell strainer was washed with PBS/ $1 \%$ HSA. The filtered cell suspension was concentrated by centrifugation at $500 \mathrm{~g}$ for ten minutes. The cells were then resuspended in $1 \mathrm{ml} \mathrm{PBS} / 1 \% \mathrm{HSA}$, and transferred to round bottom tubes for incubation with antibody-coated beads. Dynabeads M450 sheep antimouse (SAM) IgG1 (Dynal, Oslo, Norway) were coated with MOC31 antibody (batch \# 80.000, IQ products, Groningen, The Netherlands). Uncoated beads for control experiments were prepared in the same manner, without adding the MOC31 antibody. Magnetic immunobeads with or without the primary antibody were added to tubes containing the cell suspension in a final volume of $1 \mathrm{ml}$ with a bead:cell ratio of 1:2. The samples were then incubated on a rotating mixer for $30 \mathrm{~min}$ at $4{ }^{\circ} \mathrm{C}$. After incubation the samples were diluted in PBS/ $1 \% \mathrm{HSA}$ and exposed to a strong magnet for $3 \mathrm{~min}$ to separate bound and unbound cells. The supernatant containing the unbound cells was decanted off with the tubes still in the magnet holder, and the positive fraction was resuspended in PBS/1 \% HSA. Fractions of $20 \mu \mathrm{l}$ from the cell suspension were then directly examined in the light microscope to identify and count the number of cells with membrane-bound beads. The cells were also evaluated with respect to size, morphology and three-dimensional shape. Cells were considered EpCAM ${ }^{+}$if they had five or more immunomagnetic beads attached to the surface, and had diameters exceeding the width of two beads.

\section{Statistical analysis}

Associations between the presence of lymph node DTCs and clinicopathological variables were tested using twotailed Fisher's exact test or linear by linear association chi-square test. For analyses of associations between the number of DTCs detected by IMS and clinicopathological variables, two sample $t$-test or one-way ANOVA test, as appropriate, was used. Survival curves were estimated according to the Kaplan-Meier method, and differences between the curves were compared using the log rank test. Survival was measured from date of surgery until date of diagnosis of recurrence or metastasis for relapse free survival, and from date of surgery until death date for overall survival. Cox proportional hazards regression was used to estimate hazard ratios and $95 \%$ confidence intervals (CI). SPSS statistical software version 18.0 (SPSS Inc., Chicago, IL, USA) was used for all the statistical analyses. $P$-values $<0.05$ were considered statistically significant.

\section{Results}

\section{Characteristics of the patient cohort}

The clinical and histopathological baseline data of the study cohort are summarized in Table 1 . The study cohort consisted of $44 \%$ female and $56 \%$ male patients, with a mean age of 66 years (range $42-85$ ). Adenocarcinoma was the most frequent histological subtype (57\% of patients), followed by squamous cell carcinoma (39 \%) and large cell carcinoma (4\%). Sixty percent of patients were in pTNM stage I, $27 \%$ of patients were in pTNM II, $10 \%$ in pTNM III and 4 patients $(3 \%)$ were in stage IV. As assessed by standard histopathology the majority of patients $(80 \%)$ were negative for lymph node metastases and staged as pNO. Among the 26 patients in whom lymph node metastases were detected, $14 \%$ were categorized as $\mathrm{pN} 1$ and $6 \%$ as $\mathrm{pN} 2$.

Table 1 Demographics of patient cohort $(N=128)$

\begin{tabular}{|c|c|c|c|}
\hline \multirow[t]{2}{*}{ Parameter } & & \multicolumn{2}{|c|}{ Patients } \\
\hline & & $\mathrm{N}$ & $\%$ \\
\hline \multirow[t]{2}{*}{ Sex } & Male & 71 & 56 \\
\hline & Female & 57 & 44 \\
\hline \multirow[t]{2}{*}{ Age at surgery } & $<65$ years & 52 & 41 \\
\hline & $>65$ years & 76 & 59 \\
\hline \multirow[t]{3}{*}{ Histology } & Adenocarcinoma & 73 & 57 \\
\hline & Squamous cell carcinoma & 50 & 39 \\
\hline & Large cell carcinoma & 5 & 4 \\
\hline \multirow[t]{4}{*}{ UICC stage / pTNM7 } & । & 77 & 60 \\
\hline & $\|$ & 34 & 27 \\
\hline & III & 13 & 10 \\
\hline & IV & 4 & 3 \\
\hline \multirow[t]{4}{*}{ pT } & pT1 & 41 & 32 \\
\hline & pT2 & 61 & 48 \\
\hline & pT3 & 25 & 19 \\
\hline & pT4 & 1 & 1 \\
\hline \multirow[t]{3}{*}{$\mathrm{pN}$} & pNO & 102 & 80 \\
\hline & pN1 & 18 & 14 \\
\hline & pN2 & 8 & 6 \\
\hline \multirow[t]{5}{*}{ Tumour size $(\mathrm{cm})$} & $\leq 2.0 \mathrm{~cm}$ & 32 & 25 \\
\hline & $2.1-3.0 \mathrm{~cm}$ & 27 & 21 \\
\hline & $3.1-5.0 \mathrm{~cm}$ & 46 & 36 \\
\hline & $5.1-7.0 \mathrm{~cm}$ & 10 & 8 \\
\hline & $>7.0 \mathrm{~cm}$ & 13 & 10 \\
\hline \multirow[t]{3}{*}{ Tobacco use } & Current smoker & 77 & 60 \\
\hline & Former smoker & 46 & 36 \\
\hline & Never smoker & 6 & 5 \\
\hline
\end{tabular}




\section{Detection of DTCs by IMS}

In nine cases the sampled lymph node station was not registered, resulting in a total of 119 cases for the methodological analyses. Based on our experience with IMS and our previous publication [26], the cutoff for a positive sample was 10 cells, meaning that a sample with 11 or more $\mathrm{EpCAM}^{+}$cells was classified as IMS-positive. In 47 of 119 samples $(40 \%)>10 \mathrm{EpCAM}^{+}$cells were detected, and the median number of cells in the IMSpositive samples was 61 (range $14-200$ ). Between 11 and $50 \mathrm{EpCAM}^{+}$cells were detected in $45 \%$ of positive samples, $51-100 \mathrm{EpCAM}^{+}$cells were detected in $28 \%$ and $\geq 100$ cells were detected in $28 \%$ of the positive samples. Associations between the presence of $\mathrm{EpCAM}^{+}$ cells and the clinicopathological characteristics of the patients are summarized in Table 2. The presence of $\mathrm{EpCAM}^{+}$cells was significantly associated with $\mathrm{pN}$ status $(p<0.001$, Table 2$)$. Lymph node samples from 9/ 11 (82\%) pN1 patients and 5/6 (83\%) pN2 patients, respectively, were IMS-positive. Three of 17 patients

Table 2 Relationship between the presence of DTCs as detected by IMS and clinicopathological variables $\left(N=119^{\mathrm{a}}\right)$

\begin{tabular}{|c|c|c|c|c|}
\hline Parameter & & $N^{b}$ & $\%^{\mathrm{b}}$ & $p$-value \\
\hline \multirow[t]{2}{*}{ Gender } & male & 28 & 44 & \\
\hline & female & 19 & 35 & 0.36 \\
\hline \multirow[t]{2}{*}{ Age at surgery } & $<65$ years & 22 & 46 & \\
\hline & $>65$ years & 25 & 35 & 0.26 \\
\hline \multirow[t]{3}{*}{ Histology } & $\mathrm{ADC}$ & 26 & 38 & \\
\hline & SCC & 19 & 40 & \\
\hline & LCC & 2 & 50 & 0.89 \\
\hline \multirow[t]{4}{*}{ pTNM } & I & 26 & 34 & \\
\hline & $\|$ & 13 & 45 & \\
\hline & III & 7 & 78 & \\
\hline & IV & 1 & 25 & 0.12 \\
\hline \multirow[t]{4}{*}{ pT } & pT1 & 20 & 51 & \\
\hline & pT2 & 19 & 33 & \\
\hline & pT3 & 8 & 38 & \\
\hline & pT4 & 0 & 0 & 0.15 \\
\hline \multirow[t]{3}{*}{ pN } & pN 0 & 33 & 32 & \\
\hline & pN I & 9 & 82 & \\
\hline & pN ॥ & 5 & 83 & $<0.001$ \\
\hline \multirow[t]{2}{*}{ Tumor size $(\mathrm{cm})$} & $\leq 3.0 \mathrm{~cm}$ & 26 & 47 & \\
\hline & $\geq 3.1 \mathrm{~cm}$ & 21 & 33 & 0.13 \\
\hline \multirow[t]{3}{*}{ Tobacco } & Never smoker & 2 & 33 & \\
\hline & Former smoker & 20 & 47 & \\
\hline & Current smoker & 25 & 36 & 0.54 \\
\hline
\end{tabular}

${ }^{a}$ Nine patients excluded from analysis due to uncertain lymph node station

${ }^{\mathrm{b}}$ The number and percentage of positive samples are shown
(18 \%) in whom lymph node metastases were detected by histopathology (pN1-2) were categorized as IMSnegative. In the subcategory of patients who were negative for lymph node metastases by histopathology (pN0), $32 \%$ (33/102) were IMS-positive (Table 2). The exact number of $\mathrm{EpCAM}^{+}$cells in each sample was also significantly associated with $\mathrm{pN}$ status $(p<0.001$, one-way ANOVA test). In fact, 4/6 (67\%) of patients with pN2 status had more than $100 \mathrm{EpCAM}^{+}$cells in their samples, compared to only $8 / 102(8 \%)$ of the patients with pNO status. Analyzing the relationship between the IMS results and the other clinicopathological parameters revealed no association with gender, age, histology, pTNM, pT status, tumor size or tobacco smoking habits (Table 2).

\section{Patient outcome and associations with clinicopathological parameters}

For the follow-up and survival analyses the four patients with stage IV disease were excluded, resulting in a cohort of 124 patients. Median follow-up time for patients still alive who had not developed metastasis or local recurrence was 26 months (range 16 -38). Twenty-five of 124 patients $(20 \%)$ developed disease relapse, while 24 patients (19\%) died during the follow-up period. Associations between clinicopathological variables and patient outcome are shown in Table 3. Univariate analyses revealed that $\mathrm{pTNM}$ stage and $\mathrm{pN}$ status were significantly associated with disease relapse $(p<0.001$ and $p=0.001$, respectively) and with overall survival $(p=0.002$ and 0.005 , respectively). There was a significant association between patient outcome and gender, with a 2 -year relapse free survival rate of $87 \%$ for females, compared to $70 \%$ for males $(p=0.03)$. A relationship between histological subtype and patient outcome was also detected, however this result was caused by the fact that three out of four patients with large cell carcinoma relapsed, and should be interpreted with caution due to the small number of patients in the subcategory.

\section{Associations between DTCs and patient outcome}

There was a small, non-significant difference in relapse free survival between patients with IMS-negative and IMS-positive lymph node samples $(p=0.17$, Fig. $2 \mathrm{~b}$ and Table 3). Two-year relapse free survival for IMS-negative patients was $82 \%$, compared to $71 \%$ for IMS-positive patients. There was no association to overall survival $(p=0.77$, Table 3$)$. Twenty-six percent $(13 / 50)$ of patients with IMS-positive samples developed disease relapse during the follow-up period, compared to $16 \%$ $(12 / 74)$ of patients with IMS-negative samples. The exact number of $\mathrm{EpCAM}^{+}$cells detected by IMS was not associated with disease relapse $(p=0.57$, Cox univariate analysis). We performed subcategory analyses 
Table 3 Univariate analysis of associations between clinicopathological variables and patient outcome $\left(N=124^{\mathrm{a}}\right)$

\begin{tabular}{|c|c|c|c|c|c|c|}
\hline \multirow[b]{2}{*}{ Parameter } & \multicolumn{3}{|c|}{ Relapse free survival } & \multicolumn{3}{|c|}{ Overall survival } \\
\hline & $p$ & Hazard ratio & $(95 \% \mathrm{Cl})$ & $p$ & Hazard ratio & $(95 \% \mathrm{Cl})$ \\
\hline Gender & 0.03 & & & 0.9 & & \\
\hline \multicolumn{7}{|l|}{ Female } \\
\hline Male & & 2.7 & $(1.1-6.8)$ & & 1.1 & $(0.5-2.4)$ \\
\hline Age & 0.06 & & & 0.3 & & \\
\hline \multicolumn{7}{|l|}{$>65$ years } \\
\hline$<65$ years & & 2.8 & $(0.9-8.6)$ & & 1.5 & $(0.7-3.3)$ \\
\hline Histology & 0.01 & & & 0.04 & & \\
\hline \multicolumn{7}{|l|}{ Adenocarcinoma } \\
\hline Squamous cell carcinoma & & 0.7 & $(0.3-1.8)$ & & 0.5 & $(0.2-1.2)$ \\
\hline Large cell carcinoma & & 9.6 & $(2.7-34.0)$ & & 4.7 & $(1.1-20.1)$ \\
\hline pTNM & $<0.001$ & & & 0.002 & & \\
\hline \multicolumn{7}{|l|}{ । } \\
\hline$\|$ & & 1.7 & $(0.6-4.5)$ & & 2.2 & $(0.8-5.7)$ \\
\hline III & & 8.8 & $(3.4-22.4)$ & & 7.1 & $(2.6-19.2)$ \\
\hline pT & 0.07 & & & 0.02 & & \\
\hline pT1 & & & & & 1.7 & $(0.6-5.6)$ \\
\hline pT2 & & 2.4 & $(0.8-7.2)$ & & 5.6 & $(1.7-18.2)$ \\
\hline pT3 & & 4.8 & $(1.4-16.3)$ & & & \\
\hline \multicolumn{7}{|l|}{ pT4 } \\
\hline $\mathrm{pN}$ & 0.001 & & & 0.005 & & \\
\hline \multicolumn{7}{|l|}{ pNO } \\
\hline $\mathrm{pN} 1$ & & 3.6 & $(1.4-9.1)$ & & 3.5 & $(1.4-8.9)$ \\
\hline $\mathrm{pN} 2$ & & 8.2 & $(2.9-23.0)$ & & 5.1 & $(1.7-15.8)$ \\
\hline Tumor size & 0.18 & & & 0.73 & & \\
\hline \multicolumn{7}{|l|}{$\leq 3.0 \mathrm{~cm}$} \\
\hline$\geq 3.1 \mathrm{~cm}$ & & 1.7 & $(0.8-3.9)$ & & 1.2 & $(0.5-2.6)$ \\
\hline DTCs detected by IMS & 0.18 & & & 0.77 & & \\
\hline \multicolumn{7}{|l|}{ IMS negative } \\
\hline IMS positive & & 1.7 & $(0.8-3.8)$ & & 1.1 & $(0.5-2.5)$ \\
\hline
\end{tabular}

${ }^{\mathrm{a}}$ Four patients were excluded from survival analyses due to stage IV disease
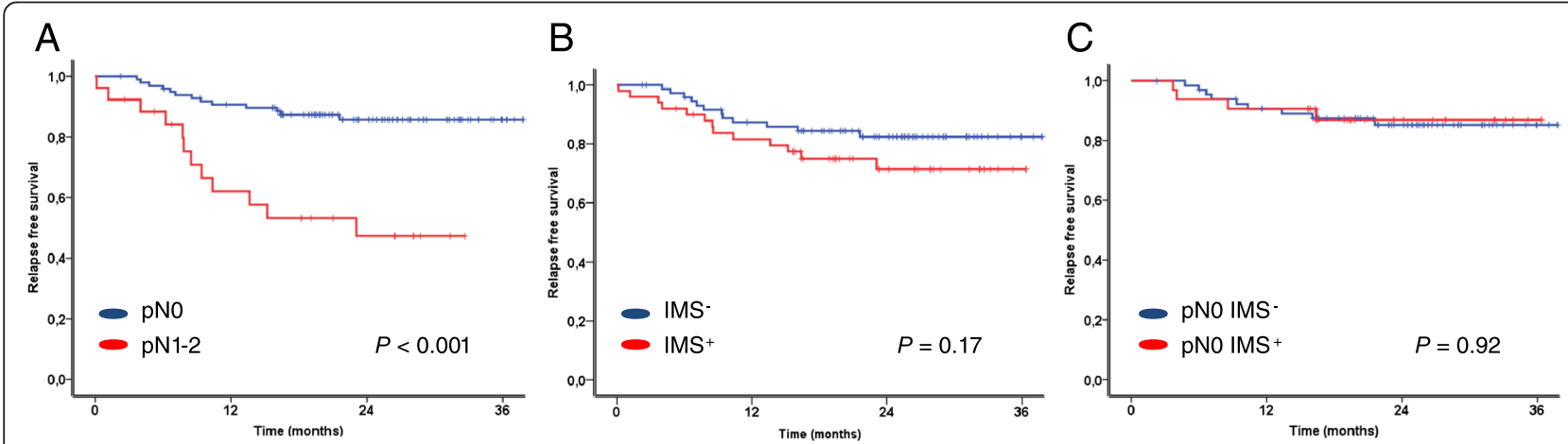

Fig. 2 Kaplan-Meier survival plots depicting relapse-free survival based on pathological lymph node status (a), and based on the presence of DTCs as detected by IMS in the overall patient cohort (b) and in the pNO patient cohort (c) 
including only patients who were classified as pN0 by histopathology, but found no difference in relapse free survival ( $p=0.92$, Fig. 2 c) or overall survival ( $p=0.39$, data not shown) between IMS-negative and IMSpositive patients. Similar to the whole patient cohort, the exact number of $\mathrm{EpCAM}^{+}$cells was not related to disease relapse in this subcategory $(p=0.57$, Cox univariate analysis). Finally, dividing patients into subcategories according to the number of $\mathrm{EpCAM}^{+}$ cells in the sample did not reveal any associations with outcome.

\section{Discussion}

In the present study we have examined the presence and prognostic implication of DTCs in prospectively collected lymph node samples from early stage NSCLC patients undergoing surgical resection. By using the technique IMS with the EpCAM-targeting antibody MOC31, we found a strong association between pN status as assessed by standard histopathology and detection of EpCAM ${ }^{+}$cells. The pN status, but not the IMS result, was significantly associated with patient outcome. Among the patients staged as pNO by histopathology, $32 \%$ were categorized as IMS-positive, but IMS was not able to predict prognosis in this patient subcategory. Taken together, we conclude that detection of lymph node DTCs by IMS does not improve nodal staging in NSCLC patients, and cannot be used for identification of patients with high risk of relapse after surgical resection.

A number of publications have investigated the incidence of micrometastatic disease or DTCs in lymph nodes from patients with NSCLC, the majority using IHC or RT-PCR, with conflicting results. Several groups have shown an association between the presence of micrometastasis or DTCs and poor prognosis $[7,8,10,11,13,14,19-23]$ while other have concluded like in our study, that their presence has no impact on patient outcome [15-18]. Data from the diverse publications are not easily comparable due to differences in methodology as well as in size and composition of patient cohorts. Also, various definitions of the terms "micrometastases", "occult tumor cells" and "isolated tumor cells" have been used, and many authors who demonstrated negative prognostic value did not specify whether they investigated isolated tumor cells or true micrometastasis $[6,14,30]$. In 2010, Herpel et al. [8] showed that nodal micrometastasis specifically defined as small tumor deposits had prognostic significance, however two other studies investigating isolated tumor cells in regional lymph nodes concluded that this did not affect survival in resected NSCLC patients $[16,17]$. One might hypothesize that NSCLC patients with detectable single DTCs have similar prognosis to patients with node negative disease, while patients with micrometastasis may have higher risk of relapse. Interestingly, similar results have been found in breast cancer [31]. In a paper from 2008, Marchevsky et al. investigated both isolated tumor cells and micrometastases in lymph nodes from 266 stage I NSCLC patients, and concluded that the presence of neither of these were significantly associated with survival. The authors also performed a meta-analysis including their own data and 13 other studies, and concluded on no significant association between micrometastasis and survival [18]. Thus, based on the current literature and our own results, detecting DTCs in regional lymph nodes does not seem to provide a clinically useful method for identifying subcategories of NSCLC patients with high risk of disease relapse. Previously we have also shown that detection of DTCs in bone marrow by IMS has no prognostic impact in early stage NSCLC patients [26].

The present study is, to our knowledge, the first to use IMS as method for detection of DTCs in regional lymph nodes from NSCLC patients. This technique was developed in our lab, and has been used in several published papers investigating DTCs in bone marrow [26, 28, 32-35] and lymph nodes [36] in various cancer types. Evaluation of morphology, size and shape of the MOC31-bead-bound cells is challenging when using IMS, and is dependent on the observer's skills and experience. In our study we found a high number of MOC31-bead bound cells in the samples, and the cut off value for an IMS-positive sample was set at 10 cells based on experience and our previous publication [26]. The high number of discovered cells might indicate that some nonmalignant cells are also detected with this method, and in fact lymph node reticulum cells can express epithelial antigens [37, 38], and weak binding of MOC31 to lymphocytes has been described [39]. Interestingly, however, in a study using RT-PCR to identify tumors cells in lymph nodes in a NSCLC cohort comparable to ours, Nordgård et al. also reported a high number of positive findings in histopathologically node negative patients [40]. Another important issue when using antibodies targeting EpCAM is that the expression of this protein may vary in tumor cells during disease progression [41], and expression can be down-regulated as a consequence of epithelial-to-mesenchymal transition (EMT) [42]. This might perhaps explain why no $\mathrm{EpCAM}^{+}$ cells were discovered in 3 of 17 lymph node samples from patients who had metastases detected by routine histopathology. There are clearly several methodological issues associated with the use of IMS, leading to considerable challenges for the further development and application of this method. 
Our study is limited by the fact that we only had access to one lymph node sample from one node station per patient. Analyzing a number of nodes from various stations from each patient would of course have been preferable. Moreover, a larger patient cohort and longer follow-up period would increase the reliability of our results. However, we were able to detect $\mathrm{EpCAM}^{+}$cells in the vast majority of samples from lymph nodes in which metastases had been shown on histopathology, and there was a strong association between results from the IMS method and nodal staging by standard histopathology.

\section{Conclusion}

We conclude that detecting $\mathrm{EpCAM}^{+}$cell in regional lymph nodes by IMS does not predict the prognosis of resected NSCLC patients, as the presence of such cells in patients who were lymph node negative showed no association with reduced survival. Our findings do not support further development of assays for detection of DTCs in lymph nodes for clinical use in NSCLC.

\section{Abbreviations}

NSCLC, non-small cell lung cancer; DTCs, disseminated tumor cells; IMS, immunomagnetic selection; UICC, Union for International Cancer Control; PBS, phosphate buffered saline; HSA, human serum albumin; CTCS, circulating tumor cells; IHC, immunohistochemistry

\section{Acknowledgements}

The authors would like to thank Ingjerd Solvoll and Ildri Haltbakk for excellent technical assistance.

\section{Funding}

This work was supported by the Research Council of Norway (grant \#191431/N50 to AKR) and the Norwegian Cancer Society (grant \#421852 to GMM and grant \#42000063406 to ØF).

The funding body had no role in the design of the study; the collection, analysis or interpretation of data.

\section{Availability of data and materials}

Not applicable. All supporting data for the conclusions are presented in the manuscript.

\section{Authors' contributions}

AKR conceived the study, carried out the immunomagnetic selection procedure, performed data analysis and wrote the manuscript. KB conceived the study and participated in writing the manuscript. $\varnothing F$ conceived the study and provided patient material. SJ performed the immunomagnetic selection procedure. LHJ and SKS provided patient material and patient data. ÅH and OTB provided patient material and patient data. GMM conceived the study and participated in writing. All authors read and approved the final manuscript.

\section{Competing interests}

The authors declare that they have no competing interests

\section{Ethics approval and consent to participate}

The project was approved by the institutional review board and The Regional Ethics Committee (S-06402b). The patients received oral and written information and signed a consent form before entering the project.

\section{Author details}

'Department of Tumor Biology, Institute for Cancer Research, Oslo University Hospital, The Norwegian Radium Hospital, PO Box 4953, Nydalen, Oslo NO-0424, Norway. ${ }^{2}$ Department of Oncology, Oslo University Hospital, The Norwegian Radium Hospital, Oslo, Norway. ${ }^{3}$ Department of Cardiovascular and Thoracic Surgery, Oslo University Hospital Rikshospitalet, Oslo, Norway. ${ }^{4}$ Department of Genetics, Institute for Cancer Research, Oslo University Hospital, The Norwegian Radium Hospital, Oslo, Norway. ${ }^{5}$ Department of Pharmacy, Faculty of Health Sciences, University of Tromsø, Postboks 6050 Langnes, Tromsø 9037, Norway.

Received: 11 January 2016 Accepted: 10 June 2016

Published online: 17 June 2016

\section{References}

1. Goldstraw P, Ball D, Jett JR, Le Chevalier T, Lim E, Nicholson AG, Shepherd FA. Non-small-cell lung cancer. Lancet. 2011;378(9804):1727-40.

2. Lardinois D, De Leyn P, Van Schil P, Porta RR, Waller D, Passlick B, Zielinski M, Lerut T, Weder W. ESTS guidelines for intraoperative lymph node staging in non-small cell lung cancer. Eur J Cardiothorac Surg. 2006;30(5):787-92.

3. Melfi FM, Lucchi M, Davini F, Viti A, Fontanini G, Boldrini L, Boni G, Mussi A. Intraoperative sentinel lymph node mapping in stage I non-small cell lung cancer: detection of micrometastases by polymerase chain reaction. Eur J Cardiothorac Surg. 2008;34(1):181-6.

4. Van Meerbeeck J, Janssen AJ. The seventh tumour-node-metastasis staging system for lung cancer: Sequel or prequel? Eur J Cancer Suppl. 2013;11(2): 150-8.

5. Balic M, Williams A, Dandachi N, Cote RJ. Micrometastasis: detection methods and clinical importance. Cancer Biomark. 2010;9(1-6):397-419.

6. Wu J, Ohta Y, Minato H, Tsunezuka Y, Oda M, Watanabe Y, Watanabe G. Nodal occult metastasis in patients with peripheral lung adenocarcinoma of $2.0 \mathrm{~cm}$ or less in diameter. Ann Thorac Surg. 2001;71(6):1772-7. discussion 1777-1778.

7. Gu CD, Osaki T, Oyama T, Inoue M, Kodate M, Dobashi K, Oka T, Yasumoto K. Detection of micrometastatic tumor cells in pNo lymph nodes of patients with completely resected nonsmall cell lung cancer: impact on recurrence and Survival. Ann Surg. 2002;235(1):133-9.

8. Herpel E, Muley T, Schneider T, Palm E, Kieslich de Hol D, Warth A, Meister M, Storz K, Schnabel PA, Schirmacher P, et al. A pragmatic approach to the diagnosis of nodal micrometastases in early stage non-small cell lung cancer. J Thorac Oncol. 2010;5(8):1206-12.

9. Chen ZL, Perez S, Holmes EC, Wang HJ, Coulson WF, Wen DR, Cochran AJ. Frequency and distribution of occult micrometastases in lymph nodes of patients with non-small-cell lung carcinoma. J Natl Cancer Inst. 1993;85(6): 493-8.

10. Verhagen AF, Bulten J, Shirango $H$, Thunnissen FB, van der Drift MA, van der Bruggen W, Tjan-Heijnen VC, van Swieten HA: The clinical value of lymphatic micrometastases in patients with non-small cell lung cancer. J Thorac Oncol, 2010:5(8):1201-1205

11. Osaki T, Oyama T, Gu CD, Yamashita T, So T, Takenoyama M, Sugio K, Yasumoto K. Prognostic impact of micrometastatic tumor cells in the lymph nodes and bone marrow of patients with completely resected stage I nonsmall-cell lung cancer. J Clin Oncol. 2002;20(13):2930-6.

12. Maruyama R, Sugio K, Mitsudomi T, Saitoh G, Ishida T, Sugimachi K. Relationship between early recurrence and micrometastases in the lymph nodes of patients with stage I non-small-cell lung cancer. J Thorac Cardiovasc Surg. 1997;114(4):535-43.

13. Passlick B, Izbicki JR, Kubuschok B, Nathrath W, Thetter O, Pichlmeier U, Schweiberer L, Riethmuller G, Pantel K. Immunohistochemical assessment of individual tumor cells in lymph nodes of patients with non-small-cell lung cancer. J Clin Oncol. 1994;12(9):1827-32.

14. Kubuschok B, Passlick B, Izbicki JR, Thetter O, Pantel K. Disseminated tumor cells in lymph nodes as a determinant for survival in surgically resected non-small-cell lung cancer. J Clin Oncol. 1999:17(1):19-24.

15. Goldstein NS, Mani A, Chmielewski G, Welsh R, Pursel S. Immunohistochemically detected micrometastases in peribronchial and mediastinal lymph nodes from patients with T1, N0, M0 pulmonary adenocarcinomas. Am J Surg Pathol. 2000;24(2):274-9.

16. Rena O, Carsana L, Cristina S, Papalia E, Massera F, Errico L, Bozzola C, Casadio C. Lymph node isolated tumor cells and micrometastases in pathological stage I non-small cell lung cancer: prognostic significance. Eur J Cardiothorac Surg. 2007;32(6):863-7.

17. Marchevsky AM, Qiao JH, Krajisnik S, Mirocha JM, McKenna RJ. The prognostic significance of intranodal isolated tumor cells and micrometastases in patients with non-small cell carcinoma of the lung. J Thorac Cardiovasc Surg. 2003;126(2):551-7. 
18. Marchevsky AM, Gupta R, Kusuanco D, Mirocha J, McKenna Jr RJ. The presence of isolated tumor cells and micrometastases in the intrathoracic lymph nodes of patients with lung cancer is not associated with decreased survival. Hum Pathol. 2010;41(11):1536-43.

19. Le Pimpec-Barthes F, Danel C, Lacave R, Ricci S, Bry X, Lancelin F, Leber C, Milleron B, Fleury-Feith J, Riquet M, et al. Association of CK19 mRNA detection of occult cancer cells in mediastinal lymph nodes in non-small cell lung carcinoma and high risk of early recurrence. Eur J Cancer. 2005; 41(2):306-12.

20. Hashimoto T, Kobayashi Y, Ishikawa Y, Tsuchiya S, Okumura S, Nakagawa K, Tokuchi Y, Hayashi M, Nishida K, Hayashi S, et al. Prognostic value of genetically diagnosed lymph node micrometastasis in non-small cell lung carcinoma cases. Cancer Res. 2000;60(22):6472-8.

21. Li J, Li ZN, Yu LC, Shi SB, Ge LP, Wu JR, Hu YM. Gene diagnosis of micrometastases in regional lymph nodes of patients with stage I non-small cell lung cancer: impact on staging and prognosis. Clin Transl Oncol. 2013; 15(11):882-8.

22. Nosotti M, Falleni M, Palleschi A, Pellegrini C, Alessi F, Bosari S, Santambrogio L. Quantitative real-time polymerase chain reaction detection of lymph node lung cancer micrometastasis using carcinoembryonic antigen marker. Chest. 2005;128(3):1539-44.

23. Dai CH, Li J, Yu LC, Li XQ, Shi SB, Wu JR. Molecular diagnosis and prognostic significance of lymph node micrometastasis in patients with histologically node-negative non-small cell lung cancer. Tumour Biol. 2013;34(2):1245-53.

24. Wang XT, Sienel W, Eggeling S, Ludwig C, Stoelben E, Mueller J, Klein CA, Passlick B. Detection of disseminated tumor cells in mediastinoscopic lymph node biopsies and lymphadenectomy specimens of patients with NSCLC by quantitative RT-PCR. Eur J Cardiothorac Surg. 2005;28(1):26-32.

25. Maeda J, Inoue M, Okumura M, Ohta M, Minami M, Shiono H, Shintani $Y$, Matsuda H, Matsuura N. Detection of occult tumor cells in lymph nodes from non-small cell lung cancer patients using reverse transcriptionpolymerase chain reaction for carcinoembryonic antigen mRNA with the evaluation of its sensitivity. Lung Cancer (Amsterdam, Netherlands). 2006; 52(2):235-40.

26. Rud AK, Borgen E, Maelandsmo GM, Flatmark K, Le H, Josefsen D, Solvoll I, Schirmer CB, Helland A, Jorgensen L, et al. Clinical significance of disseminated tumour cells in non-small cell lung cancer. Br J Cancer. 2013; 109(5):1264-70.

27. Travis WD BE, Nicholson AG, Yatabe Y, Austin JHM, Beasley MB, Chirieac LR, Dacic S, Duhig E, Flieder DB, Geisinger K, Hirsch F, Ishikawa Y, Kerr KM, Noguchi M, Pelosi G, Powell CA, Tsao MS, Wistuba I. The 2015 World Health Organization Classification of Lung Tumors. J Thorac Oncol. 2015;10(9): 1243-60.

28. Flatmark K, Bjornland K, Johannessen HO, Hegstad E, Rosales R, Harklau L, Solhaug JH, Faye RS, Soreide O, Fodstad O. Immunomagnetic detection of micrometastatic cells in bone marrow of colorectal cancer patients. Clin Cancer Res. 2002:8(2):444-9.

29. Tveito S, Andersen K, Karesen R, Fodstad O. Analysis of EpCAM positive cells isolated from sentinel lymph nodes of breast cancer patients identifies subpopulations of cells with distinct transcription profiles. Breast Cancer Res BCR. 2011;13(4):R75.

30. Passlick B. Micrometastases in non-small cell lung cancer (NSCLC). Lung Cancer (Amsterdam, Netherlands). 2001;34 Suppl 3:S25-9.

31. Van Der Heiden Van Der Loo M, Schaapveld M, Ho VK, Siesling S, Rutgers EJ, Peeters PH. Outcomes of a population-based series of early breast cancer patients with micrometastases and isolated tumour cells in axillary lymph nodes. Ann Oncol. 2013;24(11):2794-801.

32. Flatmark K, Borgen E, Nesland JM, Rasmussen H, Johannessen HO, Bukholm I, et al. Disseminated tumour cells as a prognostic biomarker in colorectal cancer. Br J Cancer. 2011;104(9):1434-9.

33. Bruland OS, Hoifodt H, Saeter G, Smeland S, Fodstad O. Hematogenous micrometastases in osteosarcoma patients. Clin Cancer Res. 2005;11(13): 4666-73.

34. Brunsvig PF, Flatmark K, Aamdal S, Hoifodt H, Le H, Jakobsen E, Sandstad B, Fodstad O. Bone marrow micrometastases in advanced stage non-small cell lung carcinoma patients. Lung Cancer (Amsterdam, Netherlands). 2008;61(2): 170-6.

35. Faye RS, Aamdal S, Hoifodt HK, Jacobsen E, Holstad L, Skovlund E, Fodstad O. Immunomagnetic detection and clinical significance of micrometastatic tumor cells in malignant melanoma patients. Clin Cancer Res. 2004:10(12 Pt 1):4134-9.
36. Tveito S, Andersen K, Karesen R, Fodstad O. Analysis of EpCAM positive cells isolated from sentinel lymph nodes of breast cancer patients identifies subpopulations of cells with distinct transcription profiles. Breast Cancer Res. 2011;13(4):R75.

37. Doglioni C, Dell'Orto P, Zanetti G, luzzolino P, Coggi G, Viale G. Cytokeratinimmunoreactive cells of human lymph nodes and spleen in normal and pathological conditions. An immunocytochemical study. Virchows Arch A Pathol Anat Histopathol. 1990;416(6):479-90.

38. Domagala W, Bedner E, Chosia M, Weber K, Osborn M. Keratin-positive reticulum cells in fine needle aspirates and touch imprints of hyperplastic lymph nodes. A possible pitfall in the immunocytochemical diagnosis of metastatic carcinoma. Acta Cytol. 1992;36(2):241-5.

39. Myklebust AT, Beiske K, Pharo A, Davies CD, Aamdal S, Fodstad O. Selection of anti-SCLC antibodies for diagnosis of bone marrow metastasis. British J Cancer. 1991;14:49-53.

40. Nordgard O, Singh G, Solberg S, Jorgensen L, Halvorsen AR, Smaaland R, Brustugun OT, Helland A. Novel molecular tumor cell markers in regional lymph nodes and blood samples from patients undergoing surgery for non-small cell lung cancer. PLoS One. 2013;8(5):e62153.

41. Grover PK, Cummins AG, Price TJ, Roberts Thomson IC, Hardingham JE. Circulating tumour cells: the evolving concept and the inadequacy of their enrichment by EpCAM-based methodology for basic and clinical cancer research. Ann Oncol. 2014;25(8):1506-16.

42. Mani SA, Guo W, Liao MJ, Eaton EN, Ayyanan A, Zhou AY, Brooks M, Reinhard F, Zhang CC, Shipitsin M, et al. The epithelial-mesenchymal transition generates cells with properties of stem cells. Cell. 2008;133(4):704-15.

\section{Submit your next manuscript to BioMed Central and we will help you at every step:}

- We accept pre-submission inquiries

- Our selector tool helps you to find the most relevant journal

- We provide round the clock customer support

- Convenient online submission

- Thorough peer review

- Inclusion in PubMed and all major indexing services

- Maximum visibility for your research

Submit your manuscript at www.biomedcentral.com/submit 